\title{
'The magic that can set you free': the ideology of folk and the myth of the rock community
}

\author{
by SIMON FRITH
}

Rock, the saying goes, is 'the folk music of our time'. Not from a sociological point of view. If 'folk' describes pre-capitalist modes of music production, rock is, without a doubt, a mass-produced, massconsumed, commodity. The rock-folk argument, indeed, is not about how music is made, but about how it works: rock is taken to express (or reflect) a way of life; rock is used by its listeners as a folk music - it articulates communal values, comments on shared social problems. The argument, in other words, is about subcultures rather than musicmaking; the question of how music comes to represent its listeners is begged. (I develop these arguments further in Frith 1978, pp. 191-202, and, with particular reference to punk rock, in Frith 1980.)

In this article I am not going to answer this question either. My concern is not whether rock is or is not a folk music, but is with the effects of a particular account of popular culture - the ideology of folkon rock's interpretation of itself. For the rock ideologues of the 1960 smusicians, critics and fans alike - rock ' $n$ ' roll's status as a folk music was what differentiated it from routine pop; it was as a folk music that rock could claim a distinctive political and artistic edge. The argument was made, for example, by Jon Landau in his influential role as reviews editor and house theorist of Rolling Stone. Rock ' $n$ ' roll, he wrote, 'was unmistakeably a folk-music form. Within the confines of the media, these musicians articulated attitudes, styles and feelings that were genuine reflections of their own experience and of the social situation which had helped produce that experience' (Landau 1972, p. 130).

There were two components to the rock-folk argument: firstly, the music was an authentic 'reflection of experience'; secondly, the music reflected the experience of a community - there was no distinction of social experience between performers and audiences. In Landau's words: 'there existed a strong bond between performer and audience, a natural kinship, a sense that the stars weren't being imposed from above but had sprung up from out of our own ranks. We could identify with them without hesitation' (ibid. p. 21).

The cultural claims made for rock by the end of the 1960 (in Carl Belz's The Story of Rock, for example) derived from the assertion that the 
music was the authentic expression of a youth community. But this was not a sociological assertion. The rock claim was that if a song or record or performance had, in itself, the necessary signs of authenticity, then it could be interpreted, in turn, as the sign of a real community - the musical judgement guaranteed the sociological judgement rather than vice versa. There was no need to provide an independent, non-musical description of the rock 'community', nor to describe how such a community came to make music for itself. What was at issue was a set of musical conventions.

Rock ideologues like Jon Landau claimed their music as folk in order to distinguish it from the rest of pop: rock was popular music that was not 'imposed from above', that did not fake emotion. 'Folk', in other words, did not describe musical production but musical values, and these values were derived from a critique of commercialism: the description of folk creation (active, collective, honest) was, in fact, an idealised response to the experience of mass consumption (fragmented, passive, alienating). If, in practice, it is difficult to discover the historical moment at which folk music turned into mass music, we can see how the development of commercial popular music pushed musical scholars into a re-examination of non-commercial popular music. And it was the scholars who first made a sharp distinction between 'folk' and 'pop' songs; the distinction was not always apparent to the people themselves (in the 1930s, for example, song collectors in the us rural South quite often recorded 'authentic' versions of songs learned from the radio a few weeks before).

The ideology of folk that was developed at the end of the nineteenth century reflected not existing musical practices but a nostalgia for how they might have been. The first folk collectors discovered and selected those songs that supported the arguments with which they began. As Sir Hubert Parry put it, folk music 'grew in the heart of the people before they devoted themselves so assiduously to the making of quick returns; and it grew there because it pleased them to make it, and what they made pleased them; and that is the only way good music is ever made' (quoted in Pearsall 1973, p. 208). The argument was that folk music was a music made directly, spontaneously, by the rural communities themselves; it was the music of working people and expressed their communal experience of work. There was no distinction between folk artist and folk audience - this point remained central to A. L. Lloyd's post-war definition of folk: 'the main thing is that the songs are made and sung by men [sic] who are identical with their audience in standing, in occupation, in attitude to life, and in daily experience' (Lloyd 1975, p. 346).

Folk songs - 'real, raw, rank and file music', to use Dave Harker's 
language - are, then, a direct contrast to pop songs - bland, escapist, artificial, produced only for the money. The problem with this argument is that, without a material analysis of how specific songs have actually been made and used, it is circular: an aesthetic judgement that folk songs are more 'authentic' than pop songs is the basis for the contrast between means of production (community creation v. commercial exploitation) which is used to explain why folk songs are more authentic than pop songs. Armed with this ideology it was easy enough for 1960 s rock fans to hear their music as more authentic than pop too; to claim that even if their music was commercial, it nevertheless symbolised a community.*

The folk argument entered rock via the American folk 'revival' of the 1940 s and 1950 os. This too was bound up with rural romanticism, with a search for values and ways which could be opposed to urban commerce and corruption. The post-war New York interest in blues and bluegrass echoed the turn-of-the-century British interest in British rural music. But if Cecil Sharp and his co-collectors were, in a sense, fearful of the urban proletariat and its music, in the USA rural nostalgia was informed by populism. In the radicals' version of folk ideology, folk music was not a source of regret (as 'organic communities' of the past were compared to the class conflicts of the present) but a source of inspiration, a way of countering the debilitating effects of the mass media and enthusing the working class with 'folk consciousness'. In the 1930s the American communist party adopted rural music as the most suitable means of expression for the urban workers; the party's intellectuals became 'people's artists' by singing folk songs dressed in Oakie clothes (see Denisoff 1971).

The American folk revival was based on a contradiction. The 'spontaneous folk creations' it celebrated were the result of musical judgements made by outsiders, by urban performers (the British folk 'tradition' was, similarly, constructed in the first place by bourgeois scholars). What was at issue was a definition of 'the people', and in the 1930 communist party music policy shifted from making 'a new kind of song, which will be so identified with the workers that nobody can take it from them', to using 'native folk consciousness and tradition - a treasury of the people's art'. The political problem was how to use music to attract people into an organisation, to develop their class consciousness; and if the tactics changed - from developing a new form of workers' music to using an old form - the cultural position did

* The most interesting recent statement of the folk argument is Harker 1980. Harker has done important historical work in clarifying the ideological bases of the British folk movement, but his own account of musical meaning is still derived from this argument. 
not: 'correct' songs were still correct in as far as they built a sense of class solidarity. The authenticity of music was, despite the folk language, still being judged by its effects rather than its sources. Even Woody Guthrie, in social terms the model performer for 1960 s rockfolk, made his music for an urban, educated audience rather than for the rural workers about whom he sang - none of Guthrie's songs was found among the Oakies and Arkies who fled the Dustbowl; their lives were already dominated by the commercial sounds of the radio and phonogram.

The radical tradition of American folk music was primarily the creation of a group of metropolitan, left-wing bohemians: their account of 'the people' was as rooted in myth and their own circumstances as was that of their more respectable, bourgeois, folk predecessors. Nevertheless, it was within the folk movement that musicians kept alive a popular music that was defined, politically and musically, in opposition to commercial pop. American folk music may have ended up, in Denisoff's sour words, as simply 'what was listened to at the informal gatherings and social affairs, at the hootenannies given by radicals', but the conventions of these gatherings were drawn on by rock musicians to justify their own claims of musical authenticity.

'Sing the truth as simply as you can', advised the Almanac Singers, 'and repeat it as many times as it has to be repeated.' The folk emphasis was on lyrics and their plain presentation; the central musical instrument was the voice and it was by reference to vocal conventions that sincerity could be judged. In people's music there were no stars or hits, no distinctions between performers and audiences, and this too was established by musical convention, by the norms of collective performance - the use of repetition and chorus and clichéd melody, the lack of vocal flourish, the restriction of instruments (guitars, piano) to accompaniment. The folk community was the community created by the musical performance itself; folk consciousness was the effect of folk singing. By the end of the 1940 os such singing was almost entirely confined to college campuses, but even at these middle-class hootenannies students could get, in Irwin Silber's ringing words, 'a sense of the real America'.

The folk revival in the 1950 s revived folk institutions - clubs, coffee houses, festivals - and it was in these settings that the 1960s folk community was defined. It was an ideological community, bound by its attitude to music-making itself. In the folk clubs there was, in theory, no separation of performer and listener - anybody could get up and sing. The aesthetic emphasis was less on technique than on truth, and the musical 'honesty' of performers was measured by what they did not do. As folk singer Jean Ray remembers: 
Young people in the sixties who had any touch on the pulse of folk music couldn't be satisfied with going and doing all the external movements of selling a song like pop singers do, with hand movements and all. It became taboo to do that. You were just to stand up straight and deliver your message. No frills. No fancy phoney stuff. (Quoted in Eliot 1979, p. 51)

Marc Eliot suggests that in the mid-sixties the New York folk scene turned its attention from 'the romance of politics to the politics of romance'; this change involved a new argument about the relationship of performer and audience, a new definition of authenticity. In 1965 Phil Ochs told a Village Voice interviewer that ' $\mathrm{I}$ 'm writing to make money. I write about Cuba and Mississippi out of an inner need for expression, not to change the world. The roots of my songs are psychological not political' (quoted in ibid. p. 93).

In the original New York folk scene, folk songs were a form of political propaganda - their aim was to invoke solidarity, to draw listeners into organisations; by the mid-sixties, folk singers were more concerned to express their individual discontent with events than to organise political responses. The criteria of sincerity began to shift from raw signs to marks of artifice; the resulting separation of artist and audience was confirmed by the development of folk-rock. Performers moved from the clubs to the studios; their records began to mean more than their appearances. This did not undercut rock's folk claims. For rock fans, Bob Dylan was a more 'authentic' singer after he went electric than before.

The political version of folk ideology obscured its own contradiction: on the one hand, folk music was an offensive weapon, an educational device, a way of driving bourgeois ideology out of working-class culture; on the other hand, folk expressed the working-class community, and this was the political significance of the folk 'tradition' - in Dave Harker's words, these songs 'must have articulated feelings and values which lay at the heart of working people's culture'. The 'authenticity' of folk songs was, then, judged in two ways: according to their musical value, and according to their class consciousness. Folk ideology equated the two measures, and it was according to this equation that folk performers could claim to represent the people, simultaneously instructing and learning from them. The people's class interests were, in other words, mediated through folk songs, and folk singers were a form of musical instrument, there to be played by the masses.

This was the position eventually rejected by singers like Bob Dylan and Phil Ochs. As they turned to rock ' $n$ ' roll, they denied that they 'represented' anyone but themselves. But the emphasis on truth remained - truth-to-self. 'The authentic folk singer', wrote Alan Lomax 
in a 1959 issue of Sing Out!, has 'to experience the feelings that lie behind his art', and it was this notion of authenticity - truth to experience rather than to class or organisation - that the 1960 s folk performers retained as they became rock singer-song-writers. They combined the folk conventions of sincerity with literary devices drawn from beat poetry; their 'authenticity' was the result of a combination of soulbaring and poetic vision.

The paradox of rock ideology in the 1960 s was that performers' claims to represent a community (unlike the usual 'plastic' pop singers) were supported by the marks of their individuality. The myth of community remains central to all the arguments about rock's cultural significance. Sociologically, rock's account of community has always been unsatisfactory. Reference is usually made (in Belz's book, for example) to the 'community of youth', but as youth is described only in terms of musical tastes, the resulting concept of community is vacuous - we are left only with windy phrases like 'the Woodstock generation'. This is not, in fact, how the myth of community works for popular music. The music (whether folk or pop or rock) is not made by a community, but provides particular sorts of communal experience. When the folk-rockers individualised the folk concept of authenticity, they changed the political principles of their performances, but they continued to offer an experience of community. This community was defined in terms of taste and sensitivity, rather than in terms of politics and ideology, but, in bringing in emotional and physical devices from rock ' $n$ ' roll, a singer like Bob Dylan intensified the effects of his music on his audiences. Such audiences may have come together only to enjoy his music, but such enjoyment came to define what community meant. As Greil Marcus put it, more generally:

We fight our way through the massed and levelled collective taste of the Top 40, just looking for a little something we can call our own. But when we find it and jam the radio to hear it again it isn't just ours - it is a link to thousands of others who are sharing it with us. As a matter of a single song this might mean very little; as culture, as a way of life, you can't beat it. (Marcus 1975, p. 115)

The rock 'community' refers not to an institution, to a set of people, but to a sensation.

The ideology of 1960s rock is still articulated in Rolling Stone. Its reviewers still consider whether this artist, this piece of music, has the right sense of rock communion; artistic excellence for Rolling Stone still lies in the authentic expression of the old myth. The rock experience 'the magic that can set you free', to quote the recurrent editorial phrase with which the paper was launched - describes the uplifting adolescent moment against which all subsequent rock ' $n$ ' roll experiences are 
to be judged, but where this moment came from, what it meant, is not examined. It is enough to name it - punk, for example, was eventually welcomed by the paper because it offered the authentic rock ' $n$ ' roll buzz: the Clash were just like the Stones! These days Rolling Stone is a consumer guide for adults. Its readers want to consume a particular sort of experience - the 1960 s experience of rock togetherness - and the paper's task is to find the musicians who can provide that experience and to explain the art with which they do it. It is the 'authenticity' of their art that guarantees the experience of rock ' $n$ ' roll community.

Rock ' $n$ ' roll started as a working-class music not just in terms of its form and content, but also in terms of its use. It was rooted in the music of travelling black and white dance bands, in a style of pleasure that was defined not by the criteria of professional entertainment, but by the urgencies of the proletarian week-end. The rock ' $n$ ' roll experience depended on a mutually nourishing relationship between the audience and the musicians, but not on shared lives. Rock ' $n$ ' roll singers were not folk, and neither were they just symbols of achievement, punk signs of what anyone could do. They were, more importantly, displaying their mastery over their lives; they were workers whose efforts were subsumed in excitement and grace, who achieved, in Roland Barthes's terms, 'the sublimation of labour by its magical effacement'. And they were workers whose efforts could be judged; their dancing audiences were not mindless. Rock ' $n$ ' roll mastery meant the mastery of movement, speed, abundance, space.

When rock became a recorded form it retained these leisure meanings but in different settings - as party music, driving music, music of the road and the street, music in control of senses and circumstances. The paradox of rock ' $n$ ' roll leisure, the effect of its success in intensifying feeling, was that it offered a sense of freedom that was, simultaneously, a sense of rootlessness and estrangement. This was the traditional theme of American popular music, black and white, folk and commercial, from 'ain't it hard to stumble, when you got no place to fall', to 'freedom's just another word for nothing left to lose', and it was focussed in rock ' $n$ ' roll by the image of the youth rebel, the loner who cannot settle down because he's got no place to go.

This paradox - leisure as an experience of freedom so intense that it becomes, simultaneously, an experience of loneliness - is rooted in working-class experience of work - in alienation. Leisure has become the only setting for the experience of self, for the exploration of one's own skills and capacities, of the creative possibilities of relations with other people. But this experience is, by its very nature, fleeting, unreal. And rock ' $n$ ' roll was American working-class music, the music of a class that has rarely been symbolised as a class. American class 
experience is mediated through historical images of individual achievement and failure; workers remember their past in terms of mobility rather than solidarity, self-sufficiency rather than socialism. Rock ' $n$ ' roll accounts of loneliness and rebellion celebrated the conditions that produced them.

The rock ' $n$ ' roll experience was an experience of community teenage community, dance-hall friendships - but this was not really central to it. The music created its community by keeping other people out, and the resulting society was transient - people grew up, tastes changed, real friends and relations were elsewhere, at home and work. Rock ' $n$ ' roll made cultural sense not as an experience in itself, but in the context of a specific experience of work and power. When rock ' $n$ ' roll became rock in the 1960 s it was removed from these contexts and drained of its original significance. Consciousness of class became a matter of self-indulgence; the rock ' $n$ ' roll experience was something which could be consumed; culture became commodity.

This is the process, often enough described (by historians of black music, for example), by which a 'folk culture' becomes mass culture. My point is that what has happened is less a change in the ways music is made than in the ways that it is used and interpreted; the move is not from 'folk' to 'mass' (both mystifying terms) but within class cultures (popular music, even when it is commercially made, involves a struggle for meaning - this is obvious in the history of punk, for example, or in the development of reggae). The usual way of analysing the ideological effects of the mass media is in terms of how they transform the collective organisations of working-class culture into the fragmented experiences of passive consumption. But the development of rock as a mass medium involved a different process: fantasies of community (drawn from images of the streets and lower-class city life) were sold to middle-class youth. The irony is that the ideology of folk was central to the resulting ideology of rock.

The rock-folk argument focussed on aesthetics: folk songs worked differently from pop songs; the folk experience was 'authentic', rooted in the experience of creation; the pop experience was unauthentic, involved only the act of consumption. In terms of musical practice (rather than scholarship or politics), the task, then, was not to develop the community that would create the right sort of music, but to use the right sort of music to communicate the lost sense of community. The emphasis (and this was obvious even in the radical aspects of the American folk revival) was on developing the appropriate conventions of performance. The use of these conventions enabled students and bohemians in their campuses and clubs to have a 'folk' experience of music without having to have a 'folk' experience of life. 'Community' 
became something that was created by the music, that described the musical experience. This was the argument that became central to the ideology of rock.

Most rock history is written in terms of a struggle between the people (musicians, fans) and the companies; the music develops through cycles of commercial control. But the most interesting question about rock is its class basis: how did rock 'n' roll, the working-class form of the 1950s, get institutionalised as a feature of middle-class, suburban youth culture?

Suburban culture is home-based, organised around family solidarity as parents and children work out their career strategies, commit themselves to sensible work at school, to the constructive use of leisure. Suburban youth learn the connection between effort and reward and live their lives as competitors - success is the measure of their selfworth. Their lives are disciplined and creative, rational and ambitious; they have to be, simultaneously, satisfied and dissatisfied with their lot. In this context, youth cultures, peer groups, are the setting not only for class competition, but also for an escape from the struggle, for irresponsibility, self-indulgence, fantasy. Music is a source of both an emotionally intensified sense of self (as artists are heard to articulate their listeners' own, private fears and feelings) and collective excitement, an illicit, immediate sense of solidarity and danger, an unbourgeois innocence of caution, an uncalculated directness and honesty. Part of the middle-class use of rock, in short, has been as a way into working-class adolescence. What is on offer is the fantasy community of risk - such a use of music has a long history: in the 1920 S and 1930s, middle-class adolescents were, for similar reasons, drawn to jazz.

The street culture that fascinates the suburban young is a romanticised version of the culture of working-class peer groups who, pushed around at home, school and work, claim their own territory literally, as they appropriate their material environment - streets and cafés and pubs and parks - from the people who really control it. For these teenagers the sense of class is the sense of place: it is their streets which must be defended, it is on the streets that status is won, that 'them' and ' $u$ s' are visible. This culture, again, has a long history, stretching back through a hundred years of city gangs. For such groups - more or less organised, more or less criminal, more or less desperate - music is little more than the background sound of activities, 'the small coin of social exchange', in Graham Murdock's words.

In understanding the myth of the rock community we have to understand how the street experience of leisure - dance-hall drunks, doing nothing, tedium and laughs, fighting and male fellow-feeling - 
has been sentimentalised, distanced, organised into the rock ' $n$ ' roll experience. Rock ' $n$ ' roll, in other words, has celebrated street culture both for its participants and for its suburban observers, and by the mid-196os such a celebration meant more to the latter group. American observers at the time were prone to describe such celebrations in religious terms: rock concerts were ceremonies of the spiritual communion of youth. But this was to evade the complexity of the relationships between work and play, class and ideology, the fantastic and the real.

If working-class street culture is a romantic idea for 'rebel' suburban kids - a fantasy of spontaneous style and pleasure and excitement - so is the student community a romantic idea for 'rebel' street kids - a fantasy of self-exploration, sexual freedom, art and Angst. These are fantasies about leisure, about different ways of life, about different possibilities of community; and my final point is this: the importance of the myth of rock community is that it is a myth. The sociological task is not to 'expose' this myth or to search for its 'real' foundations, but to explain why it is so important. Just as the ideology of folk tells us little about how folk music was actually made but much about the folk scholars' own needs and fancies, so rock myths 'resolve' real contradictions in class experiences of youth and leisure. The significance of magic is that people believe in it.

\section{References}

Belz, Carl, The Story of Rock (New York, 1969).

Denisoff, R. Serge, Great Day Coming (Urbana, 1971).

Eliot, Marc, Death of a Rebel (New York, 1979).

Frith, Simon, The Sociology of Rock (London, 1978).

'Music for pleasure', Screen Education, 34 (1980), pp. 51-61.

Harker, Dave, One for the Money: Politics and Popular Song (London, 1980).

Laing, Dave (ed.), The Electric Muse (London, 1975).

Landau, Jon, It's too Late to Stop now (San Francisco, 1972).

Lloyd, A. L., Folk Song in England (London, 1975).

Marcus, Greil, Mystery Train (New York, 1975).

Pearsall, Ronald, Victorian Popular Music (Newton Abbot, 1973). 